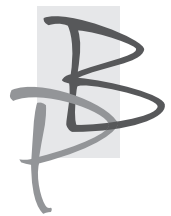

\title{
Andrzej Baranow*
}

Uniwersytet w Białymstoku

https://orcid.org/0000-0003-4787-5384

\section{Anna Kaupuż i jej tajemnicza korespondencja z Aleksandrem Sołżenicynem}

Streszczenie: Anna Kaupuż (1924-1994), zapomniana polonistka, przez całe życie związana była z Wileńskim Uniwersytetem Pedagogicznym. Dorobek badaczki, prace literaturoznawcze i lingwistyczne, organicznie wpisuje się do filologii współczesnej. Kontekst uniwersalny jej badań (Adam Mickiewicz, Baudouin de Courtenay) był ściśle połączony z wymiarem lokalnym (działalność profesora Uniwersytetu Wileńskiego Iwana Łobojki, specyfika języka polskiego na Litwie), dlatego jej studia porównawcze można rozpatrywać w kategoriach komparatystyki dyskursywnej i kulturowej. Szczególnie warta uwagi okazuje się korespondencja Kaupuż z rosyjskim pisarzem Aleksandrem Sołżenicynem, którego listy (w j. rosyjskim i tłumaczeniu na j. polski) prezentowane są w niniejszym artykule.

Słowa-klucze: Anna Kaupuż, Aleksander Sołżenicyn, komparatystyka, dyskurs, lingwistyka.

Andrzej Baranow - dr hab., prof. UwB; kierownik Pracowni Komparatystyki Kulturowej na Wydziale Filologicznym Uniwersytetu w Białymstoku; przez lata pracował na Litewskim Uniwersytecie Edukologicznym (Wilno) (obecnie: Akademia Edukacji Uniwersytetu Witolda Wielkiego w Kownie, oddział w Wilnie). Opublikował monografię zatytułowaną: Dostojewski i literatura polska (do 1918 roku) (Wilno 2001). 


\section{Anna Kaupuż and her secret letters with Aleksandr Solzhenitsyn}

Summary: Anna Kaupuż (1924-1994), a forgotten Polish scholar, was closely connected with Vilnius Pedagogical University throughout her whole life. Her literary and linguistic heritage is an integral part of contemporary philology. The universal context of her research (Adam Mickiewicz, Boduen de Courtenay) was closely related to the local situation (activities undertaken by Ivan Lobojko, a professor at Vilnius University, the specificity of the Polish language in Lithuania). Her work can be explored within the categories of comparative discourse and culture. The intellectual legacy of Kaupuż lies in her correspondence with the Russian writer Aleksandr Solzhenitsyn, whose unknown letters are presented in the present article.

Key words: Anna Kaupuż, Aleksandr Solzhenitsyn, comparative studies, discourse, linguistics.

\section{Wstęp}

Anna Kaupuż - w swoich czasach osobowość nietuzinkowa, jako badaczka literatury wzbudza zainteresowanie również wśród współczesnych. Urodziła się w 1924 roku, zmarła w 1994. Jest pochowana w Rydze. W roku 2019 obchodzimy zatem dwie pół-okrągłe rocznice, zarówno jej urodzin, jak i śmierci.

W roku 2010 w Studiach nad polszczyzną kresowa pod redakcją Janusza Riegera opublikowano nieduży artykuł o charakterze informacyjno-opisowym autorstwa Ireny Masojć i Zofii Sawaniewskiej-Mochowej Anna Kaupuż - zapomniana badaczka polszczyzny i związków międzykulturowych na Kresach. Wśród dostępnych dzisiaj, nader skąpych informacji o tej wybitnej osobie, syntetyczny charakter ma jeden artykuł: Anna Kaupuż (1924-1994), zamieszczony w „Kwartalniku Historii, Nauki i Techniki”', w którym tytułowa

1 I. Masojć, Z. Sawaniewska-Mochowa, Anna Kaupuż - zapomniana badaczka polszczyzny $i$ zwiazków międzykulturowych na kresach, [w:] Studia nad polszczyzna kresowa, pod red. J. Riegera, Warszawa 2010, s. 9-17; „Kwartalnik Historii, Nauki i Techniki” 1995, 40, nr 3, s. 171-174. 
bohaterka uznana została za „zapomnianą”. Wydaje mi się, że określenie owo staje się zdecydowanie niewystarczające w przypadku polonistki z Łatgalii. Jej dorobek organicznie wpisuje się w ramy współczesnego literaturoznawstwa.

Poznałem Annę Kaupuż jeszcze jako młodzieniec, czyniąc pierwsze kroki na niwie polonistycznej podczas konferencji na Uniwersytecie Moskiewskim imienia Łomonosowa. To pierwsze spotkanie pozostaje w moich wspomnieniach. Pamiętam, że nazwała ona wówczas samą siebie Łatgalką. Pochodzenie miało na zawsze zakorzenić się w jej pamięci genetycznej. Była to osoba światła, uduchowiona, lekko się z nią rozmawiało o skomplikowanych sprawach naukowych. Z drugiej strony, odczuwało się, że jest nieco skryta, zagadkowa, tajemnicza. Myślę, że to cechy nieprzypadkowe, jeżeli nawiązać do imagologii.

\section{Światly czlowiek oraz zaangażowany naukowiec i dydaktyk}

Miała życie trudne. Mieszkając w Leningradzie, przeżyła w czasie wojny jego oblężenie. Jej udziałem stała się następnie ewakuacja w głąb Rosji, do obwodu kirowskiego. W roku 1944 wróciła do Leningradu, gdzie skończyła studia na Wydziale Filologicznym Leningradzkiego Uniwersytetu Państwowego (kierunek filologia słowiańska). Po studiach otrzymała przydział do pracy w Wilnie. W Wileńskim Państwowym Instytucie Pedagogicznym kierowała Katedrą Języka Polskiego i Literatury.

W opinii studentów i pracowników Anna Kaupuż to przede wszystkim bardzo zaangażowany naukowiec i dydaktyk. Świetnie znając temat i lubiąc prowadzone zajęcia, była osobą wymagającą wobec podopiecznych, starała się przekonać ich do wartości słowa, zwracała uwagę na jego najsubtelniejsze odcienie znaczeniowe, co szczególnie uwydatniało się w toku zajęć z „Lingwistycznej analizy tekstu". Na spotkaniach, głównie typu ćwiczeniowego, studenci, znający swoją profesor przede wszystkim jako językoznawczynię, mogli podziwiać także jej erudycję literaturoznawczą, gdyż obiektem analizy często stawały się teksty literackie, zwłaszcza poetyckie. Wnikanie w różne subtelności liryki, na przykład Leopolda Staffa czy Marii Pawlikowskiej-Jasnorzewskiej, sprawiało, że nieduży objętościowo tekst wystarczył na całą godzinę akademicką. Nie wszyscy i nie od razu doceniali takie podejście, jednakże po latach, szczególnie dla tych wychowanków, którzy podjęli pracę w szkole bądź na uczelni, ten sposób interpretacji okazał się niezwykle przydatny. 
Anna Kaupuż była także animatorem studenckiej działalności naukowej. Przez długie lata sprawowała opiekę nad odbywającymi się corocznie studenckimi konferencjami naukowymi, podrzucając początkującym badaczom ciekawe tematy. Wykrywszy w kimś głębszą iskierkę, starała się zachęcać do podjęcia badań poważniejszej natury. Kiedy jednak proszono ją, żeby oficjalnie pokierowała pracą, zostając, na przykład, promotorem, grzecznie odmawiała. Chodziło zapewne o ostrożność wynikającą z faktu, że w czasach, które, jak mówi poeta, „były zaiste opowieścią idioty”2, trudno kierować kimkolwiek i czymkolwiek, gdyż było się zmuszanym do rezygnowania ze swoich przekonań i w dodatku do narzucania młodym badaczom cudzej woli. W takich zatem wypadkach skromnie argumentowała, że zna innych, „,bardziej kompetentnych" naukowców i może ułatwić z nimi kontakt, co też zresztą czyniła.

W obcowaniu ze wpółpracownikami nie była wielosłowna. Niewiele miała do powiedzenia na tematy „bytowo-obyczajowe”. Kiedy jednak dyskurs powracał na tory dydaktyczne, a zwłaszcza naukowe, zawsze zabierała kompetentnie głos. To właśnie ona spośród wszystkich współpracowników katedry najwięcej godzin spędzała w bibliotekach i archiwach (czasem nawet kosztem nielubianej pracy administracyjnej), najczęściej jeździła na konferencje, publikowała artykuły, nawiązywała kontakty z naukowcami z Litwy i Polski, co w okresie radzieckim nie było zadaniem łatwym.

Trudno ściśle określić obszar jej zainteresowań naukowych. Była wprost filologiem w uniwersalnym i podniosłym znaczeniu tego słowa. Kochała kulturę polską i była komparatystką w czasach, kiedy „komparatystyka” oznaczała zajęcie właściwie zabronione w Związku Radzieckim. Aby złagodzić potencjalne restrykcje, używano terminu ,literatura porównawcza” (сравнительное литературоведение). Jej pierwsza rozprawa naukowa, praca dyplomowa, obroniona na Uniwersytecie Leningradzkim, nosiła tytuł „Sonety krymskie” Adama Mickiewicza w Rosji. Jej artykuły Kochanowski na Litwie. Przekłady tekstów Jana z Czarnolasu na język litewski³, O litewskich przekładach Adama

2 Z. Herbert, Wiersze zebrane, oprac. R. Krynicki, Kraków 2008, s. 585.

3 A. Kaupuż, Kochanowski na Litwie. Przekłady tekstów Jana z Czarnolasu na język litewski, [w:] Jan Kochanowski 1584-1984. Epoka - twórczość - recepcja. Prace Międzynarodowej i Międzydyscyplinarnej Konferencji Naukowej, zorganizowanej w Warszawie 15-19 października 1984 r. staraniem Instytutu Badań Literackich i innych instytucji, T. II, pod red. J. Pelca, P. Buchwald-Pelcowej i B. Otwinowskiej, Lublin 1989, s. 79-95. 
Mickiewicza $a^{4}$ można powiedzieć, że wyprzedzały czasy, niektóre interpretacje i rozważania można dziś traktować w kategoriach komparatystyki kulturowej i dyskursywnej. Badaczka w szczegółach i bardzo głęboko porównywała różne przekłady Mickiewicza na język litewski. Szukała światła, które pojawia się między językami i łączy oryginał oraz tekst tłumaczony. Przekłady omawiała między innymi w nurtach strukturalno-językowym i typologiczno-mentalnym, chociaż terminów, które zna translatoryka współczesna, nie używała.

Rozprawa doktorska, obroniona w roku 1971 na Uniwersytecie w Leningradzie, nosiła tytuł Szkice z dziejów filologii stowiańskiej Uniwersytetu Wileńskiego na poczatku XIX wieku i otwierała nowy kierunek badań filologicznych i jednocześnie archiwalnych. Autorka bardzo dobrze czuła się w archiwach, była w nich zadomowiona. Wydobywała nieraz na światło dzienne zapomniane albo zupełnie nieznane nazwiska i zjawiska. Taki charakter ma na przykład rozprawa w języku rosyjskim Некоторые дополнительные сведения о литовских деятелях культуры начала ХХ века в письмах проф. русской словесности И. Н. Лобойко ${ }^{5}$. Pochodzący z Ukrainy Iwan Łobojko był profesorem języka i literatury rosyjskiej Uniwersytetu Wileńskiego. Porównywał języki słowiańskie, znał język duński, interesował się dawnym piśmiennictwem skandynawskim. Dla polonisty współczesnego ciekawe są jego kontakty z Mickiewiczem.

Wypada stwierdzić, że nie możemy badać XIX-wieczności i litewsko-polskich związków kulturowych bez uwzględnienia prac Anny Kaupuż. Badaczka odkryła dużo tekstów ważnych także dla polonistyki i lituanistyki' ${ }^{6}$. Dzięki jej wysiłkom odnaleziono w archiwach wileńskich Podręcznik czystej polszczyzny dla Litwinów i petersburszczan autorstwa Jana Karłowicza.

Jako dydaktyk była związana raczej z lingwistyką. Fachowo prowadziła wykłady i ćwiczenia z takich przedmiotów, jak gramatyka historyczna, współczesny język polski, dialektologia, lingwistyczna analiza tekstu. Dydaktyka

4 A. Kaupuż, O litewskich przekładach Mickiewicza, „Rocznik Towarzystwa Literackiego im. Adama Mickiewicza” XII, 1979, s. 75-82.

5 А. Каупуж, Некоторые дополнительные сведения о литовских деятелях культуры начала XIX века в письмах проф. русской словесности Виленского университета И. Н. Лобойко, [w:] „Научные труды высших учебных заведений Литовской ССР, «Литература» VI, Вильнюс 1963, с. 207-221.

6 Zob. A. Kaupuż, Nežinomas XIX a. pradžios rankraštis lietuvių ir lenku kalbomis, [w:] „Lietuvos TSR Aukštujų mokyklų mokslo darbai“, „Literatūra“ VIII, Vilnius 1965, s. 233-272. 
pięknie łączyła się z nauką7. Badania sięgały nie tylko historii i specyfiki języka polskiego na Litwie ${ }^{8}$, ale znacznie dalej, bo także egzotycznego dialektu języka słoweńskiego. Mam na myśli artykuł wydany we Wrocławiu w języku rosyjskim: Материаль к истории изучения резьянских говоров 9 .

Nie zdążyła obronić habilitacji na temat Jan Baudouin de Courtenay i jego kontakty z rosyjskimi i polskimi naukowcami. Kompendium, obejmujące 500 stron maszynopisu, przechowuje Litewskie Archiwum Historyczne.

Rozprawy Anny Kaupuż były publikowane w pismach polskich - mówiąc językiem współczesnym - wysoko punktowanych, rangi „Slavia Orientalis". Niestety, naukowcy współcześni rzadko korzystają z dorobku naukowego badaczki. Jej nazwisko występuje marginalnie w linkach internetowych. Potrzebne staje się zatem gruntowne i systematyczne odczytanie jej dorobku w kontekście humanistyki współczesnej.

\section{Nieznana korespondencja z rosyjskim noblistą}

Pisałem o skrytym charakterze Anny Kaupuż. To, co nosiła w sobie zagadkowego, zaczęło się z czasem powoli odsłaniać. Była osobą inteligentną w pojęciu klasycznym, typowym dla początku XX wieku. Utrzymywała duchowy kontakt z rosyjskim dysydentem Aleksandrem Sołżenicynem. Ukrywała, że z nim koresponduje. Była bardzo otwarta na kontakty i zarazem bardzo ostrożna. Kiedy do Wilna przyjechała znana współcześnie lingwistka warszawska, Anna Kaupuż, idąc na spotkanie z nią w hotelu „Neringa”, poszła o piętro wyżej. To nie mania prześladowcza, lecz zachowanie typowe dla osoby pozostającej w opozycji do władz w zdeformowanej przestrzeni Związku Sowieckiego, gdzie często dochodziło do groteski. KGB w republikach bałtyckich miało nieco inny sposób działania niż w Rosji. W Wilnie istniała kawiarnia, która skupiała dysydentów byłego Związku Radzieckiego, z daleka obserwowanych przez bezpiekę.

7 A. Kaupuż, W sprawie udziatu Jana Baudouina de Courtenay w redagowaniu stownika Antanasa Juški, [w:] Batto-stowiańskie zwiąki językowe, pod red. M. Kondratiuka, Wrocław-Warszawa-Kraków 1990, s. 187-197.

8 А. Каупуж, Из истории польской орфографии в Вильне в первой трети ХІХ века, „Acta Baltico-Slavica” VIII, 1973, c. 169-181.

9 А. Каупуж, Материальь к изучению истории резьянских говоров, [w:] Wokót języka. Rozprawy i studia poświęcone pamięci profesora Mieczysława Szymczaka, red. M. Basaj i inni, Wrocław 1988, s. 191-195. 
Listy Sołżenicyna do Anny Kaupuż są interesujące przede wszystkim dlatego, że odsłaniają nieznaną kartę życia badaczki, obnażają jej zainteresowania kulturowe, co w ukryty sposób miało odbicie w jej działalności naukowej. $\mathrm{Z}$ drugiej strony, korespondencja uwypukla warte uwagi niuanse osobowości Sołżenicyna, zawiera informację z pierwszych rąk o recepcji jego utworów w Rosji, o skomplikowanych stosunkach pisarza z redakcją pisma „Новый мир” na czele z Aleksandrem Twardowskim. Korespondencja zrodziła się w zaskakujący sposób. Ostrożna Anna Kaupuż napisała list do autora Archipelagu Gułag. Zafascynowało ją opowiadanie Один день из жизни Ивана Денисовича. Wymyśliła sobie pseudonim Kaupuż Anika Władisławowicz. Kupiła bilet do Leningradu, pojechała tam na jeden dzień, żeby wysłać stamtąd list. To była konspiracja. Zachowała nawet bilety niektórych wyjazdów do Leningradu.

List z 14 stycznia 1963 roku:

Уважаемый т. Каупуж! Благодарю Вас за Ваши теплые письма. Я их получил все три, но занятость помешала мне ответить своевременно. Признателен Вам за польские вырезки, хотя по-польски я не читаю, а так, с пятого на десятое догадываюсь по похожим словам.

Прошу Вас написать кое-что о себе: кто вы? чем занимаетесь? давно ли живете в Вильнюсе и как же Вас зовут?

Минувшим летом я был в Вильнюсе /на велосипедах с приятелем мы пересекли Латвию и Литву/15.8. ездил в Тракай и при этом проезжал и по Вашей улице Басанавичяус. Много в Вильнюсе произвело на меня впечатление, хотя в общем город меня не увлек /а движение газогенераторных автомобилей по узким средневековым улицам просто-таки отрава для легких/.

Еще раз благодарю. Вы верно замечаете, что рецензии, наши и заграничные, относятся почти сплошь к теме, а не к художественной стороне повести. Что ж, вероятно, этого не избежать на первых порах.

[Szanowny T. Kaupuż! Dziękuję za Pańskie ciepłe listy. Otrzymałem je trzy naraz, ale obowiązki przeszkodziły mi odpowiedzieć w terminie. Jestem Panu wdzięczny za polskie wycinki, chociaż nie czytam po polsku, 
a tak, piąte przez dziesiąte, domyślam się na podstawie przedłożonych mi słów.

Proszę Pana o napisanie czegoś o sobie: kim Pan jest? czym się Pan zajmuje? czy od dawna mieszka Pan w Wilnie? I wreszcie, jak Pan się nazywa?

Ubiegłego lata byłem w Wilnie / rowerami z przyjacielem przecięliśmy Łotwę i Litwę/. 15.8. jeździłem do Trok i w związku z tym jechałem po Pańskiej ulicy Basanavičiusa. Wiele miejsc Wilna wywarło na mnie duże wrażenie, chociaż w sumie miasto mię nie urzekło / a ruch samochodów gazogeneratorowych po wąskich średniowiecznych ulicach jest po prostu trucizną dla płuc/.

Jeszcze raz dziękuję. Pan słusznie zauważa, że recenzje nasze i zagraniczne ustosunkowują się prawie wyłącznie do tematu, nie zaś do strony artystycznej opowieści. Cóż, zapewne nie da się tego tymczasem uniknąć.]

List z 1 lutego 1963 roku:

Уважаемый Аника Владиславович? Я аккуратно получаю Ваши письма с вырезками. Благодарю Вас за внимание. Если это занятие Вам не надоест, Вы можете присылать вырезки и впредь /в Польше, как я представляю, богатая духовная жизнь и поэтому мнение поляков не может меня не интересовать/, но упростите себе эту работу: сократите количество вырезок, выбирайте самые любопытные и не трудитесь вырезать заголовки самих газет. На мою способность понимать польский текст особенно не полагайтесь, Ваши краткие печатные резюме дают мне больше, чем самый текст.

[Szanowny Anika Władysławowiczu? Akuratnie otrzymuję Pańskie listy z wycinkami. Dziękuję Panu za uwagę. Jeżeli to zajęcie Pana nie znuży, może Pan nadal przysyłać wycinki / w Polsce, jak sobie wyobrażam, bogate życie duchowe i dlatego zdanie Polaków nie może mnie nie interesować/, ale proszę ułatwić sobie tę pracę: proszę skrócić liczbę wycinków, wybierać najbardziej ciekawe i nie trudzić się wycinaniem nagłówków samych gazet. Na mojej zdolności rozumienia tekstu polskiego proszę szczególnie nie polegać, Pańskie krótkie drukowane streszczenia dają mi więcej niż sam tekst.] 
W listach pisarza rosyjskiego często pojawia się forma „my”. Chodziło tu o jego pierwszą żonę, Natalię Reszetowską.

Kolejne fragmenty listów Sołżenicyna nawiązują do dyskursu wewnętrznego. Oto list noblisty z 29 maja 1963 roku:

„Милый Аника Владиславович! Я очень признателен Вам за Ваши теплые письма и за информацию, которую с интересом читал. Этим летом в июле мы будем в Прибалтике, но не знаю, сумеем ли заглянуть в Вильнюс. [...] Жму Вашу руку.»

[Miły Anika Władysławowiczu! Jestem Panu bardzo wdzięczny za ciepłe listy oraz informację, którą z ciekawością czytałem. W lipcu tego lata będziemy w Nadbałtyce, ale nie wiem, czy potrafimy zajrzeć do Wilna. [...] Ściskam Panu dłoń.]

Rosnące napięcie zmuszało do odsłonięcia prawdziwej twarzy nadawczyni listów. W późniejszym liście Sołżenicyna czytamy:

«Милая Анна Владиславовна! Ваш небольшой обман совершен из добрых соображений, и я не могу из-за него на Вас сейчас рассердиться или упрекнуть. Примем и усвоим Вас в новом виде [...] Вместе с Вами сожалею о судьбе «Нова Культура» и «Пшегленда Культуральскего». [chodzi o „Przegląd Kulturalny” - А. В.] Пишите, пожалуйста, мы рады Вашим письмам. А я то вспоминаю, обилие безличных оборотов в Ваших письмах - приписывал недостаточному владению русским языком [...]. Теперь, когда печать с Ваших уст снята, - может быть Вы напишете о себе немножко больше? И кстати, В. Каупуж, министр культуры Лат ССР (его статья попалась нам недавно) - однофамилец или родственник Ваш?»

[Miła Anno Władysławowna! Niewielkie Pani oszustwo dokonało się z dobrymi intencjami, więc nie mogę się na Panią gniewać czy coś Pani zarzucić. Zaakceptujemy i zapamiętamy Panią w nowym obliczu [...]. Razem z Panią ubolewam nad losem „Nowej Kultury” i „Przeglądu Kulturalskiego"(sic!). Proszę pisać, cieszą nas Pani listy. Ja zaś wspominam mnogość 
zwrotów bezosobowych w Pani listach - przypisywałem to niedostatecznej znajomości języka rosyjskiego [...] Teraz, kiedy zdjęta została już pieczęć z ust - może nieco więcej napisze Pani o sobie? A tak, na marginesie, W. Kaupuż, Minister Kultury Łot. SRR (jego artykuł trafił niedawno w nasze ręce) - imiennik czy Pani krewny?]

W dalszych listach narracja się zmienia, pojawiają się inne formy honoryfikatywne (1 stycznia 1966):

Пусть в этом году Вам будет лучше чем в прошлом! Несмотря на оживление, Вы мне показались печальной. Кончая это письмо, хочу не пожать Вам руку, а - поцеловать.»

[Niech ten rok będzie dla Pani lepszy niż miniony! Bez względu na ożywienie, Pani wydała mi się smutna. Kończąc ten list, chcę Pani rękę nie uścisnąć, lecz - ucałować.]

Anna Kaupuż była pośrednikiem Sołżenicyna w poznawaniu kultury polskiej i okoliczności jej rozwoju, skomplikowanego kontekstu politycznego epoki PRL-u.

Listy nasycone są w jakimś stopniu artyzmem i eksponują poetykę codzienności, czego przykładem jest stosunek pisarza do stolicy Litwy, najpierw powierzchowny, następnie coraz bardziej pogłębiony, wnikający w osobliwości kultury i architektury miasta. List z 11 czerwca 1965 roku:

«Милая Анна Владиславовна! Мы ничуть не жалеем, что в Вильнюсе были в воскресение: с приятностю вспоминаем платную содержательную поездку по городу, и наш гид нас вполне удовлетворил. Поэтому не кляните себя ни за что и воздержитесь от штудирования труда доктора Орды «Символика скульптур Костела Петра и Павла». Необьятного не объять. Спасибо за самоотверженное намерение и за те дополнительные разъяснения, которые Вы прислали теперь.

Перевес архитектуры над литературой у нас, действительно, во встречи был, но это уж из-за краткости. В другой раз исправим. Пьесы 
Мрожека в Вашем пересказе заставляют думать, что польский театр поживее нашего, и намного. Очень хороши, видимо.

Единственная справка, которую нам еще хотелось бы навести после того, как мы проехали Литву, это: чья скульптура Скорбная Мать и памятник в деревне Пирчюпис в честь ста с чем-то погибших? Нам очень понравилось. Еще раз хотим поблагодарить Вас за Ваше внимание и расположение к нам. Едва не заточенные вместе с Вами во дворе Костела Петра и Павла.

[Miła Anno Władysławowna! Wcale nie żałujemy tego, że byliśmy $\mathrm{w}$ Wilnie $\mathrm{w}$ niedzielę. Z przyjemnością wspominamy płatną treściwą przejażdżkę po mieście i nasz pilot w pełni nas zadowolił. Dlatego proszę o nic siebie nie winić i powstrzymać się od studiowania dzieła doktora Ordy Symbolika rzeźb w kościele Piotra i Pawła. Nieogarnionego nie sposób ogarnąć. Dziękujemy za ofiarny zamiar i za te dodatkowe komentarze, które Pani teraz przysłała.

Przewaga architektury nad literaturą rzeczywiście była obecna w naszym spotkaniu, lecz to ze względu na krótkość. Następnym razem wyrównamy. Sztuki Mrożka w Pani przekazie zmuszają do myślenia, że teatr polski żywszy od naszego, i to o wiele. Bardzo dobre zapewne.

Jedyne, czego chcielibyśmy się dowiedzieć po tym, jak objechaliśmy Litwę, to: czyje są figura Matki Bolesnej i pomnik we wsi Pirčiupis ku czci ponad stu poległych? Bardzo nam się podobały. Jeszcze raz chcemy Pani podziękować za uwagę i przychylność nam. Ledwo nie uwięzieni razem z Panią w dziedzińcu kościoła Piotra i Pawła.]

Dyskurs wewnętrzny zawierał różnego rodzaju dyskusje, polemiki, a głos Anny Kaupuż był bardzo ceniony. Z korespondencji wynika, że naukowczyni miała własne zdanie, w sposób krytyczny odczytywała powstające utwory noblisty. Dyskursy te były dla Sołżenicyna drogowskazem, zmuszającym do uwzględnienia opinii inteligentnego odbiorcy, zanurzonego w kulturze polskiej.

List z 4 września 1963 roku:

«Милая Анна Владиславовна! [...] Нельзя даже ставить себе задачи - все писать на одном уровне. Даже у позднего Чехова /не говорю 
о раннем/ Вы можете найти «Ариадну» или «О любви» - почти в те же годы, что «Душечка» и «Новая дача».

Так же я разочарую Вас, если Вы ждете от меня всегда лиричности. И я не считал бы себя писателем и не совался бы туда, если бы я мог передавать мироощущение лишь «близКих по духу» героев. Я хотел бы уметь передать изнутри любого наперед заданного героя, первого встречного на дороге. Это же трудней гораздо.

И так, приготовьтесь к тому, что я, может быть, не совсем такой, каким Вы меня представили по «Ивану Денисовичу» и «Матрене».

Еще раз благодарю - и прошу и впредь писать все неприятное, что Вам захочется мне высказать. Это полезно очень.

[Miła Anno Władysławowna! [...] Nie sposób nawet stawiać przed sobą zadania - wszystko pisać na jednym poziomie. Nawet u późnego Czechowa /nie mówię o wczesnym/ może Pani znaleźć Ariadnę albo O miłości - prawie w tych samych latach, co Duszyczka i Nowe letnisko.

A zatem rozczaruję Panią, jeżeli Pani zawsze oczekuje ode mnie liryczności. Nie uważałbym siebie za pisarza i nie wchodziłbym w to, gdybym mógł przekazywać światoodczucie tylko bliskich mi duchowo bohaterów, chciałbym potrafić przekazać świat wewnętrzny dowolnego pomyślanego przedtem bohatera, pierwszego spotkanego na drodze. To jednak znacznie trudniejsze.

Tak więc, proszę przygotować się do tego, że, być może, nie jestem taki, jakiego Pani sobie wyobraziła na podstawie Iwana Denisowicza i Matriony.

Jeszcze raz dziękuję oraz proszę nadal pisać o wszystkim nieprzyjemnym, co Pani zechce mi powiedzieć. To bardzo pożyteczne.]

List z 22 lutego 1966 roku:

«Милая Анна Владиславовна! Благодарю Вас за очередной бескомпромиссный отзыв. Пожалуйста, такой оставайтесь и всегда!

С интересом обдумаю то, что Вы написали /я не часто соглашаюсь сразу, иногда потом тольКо/. Что это не рассказ в полном смысле - конечно, есть и публицистика и очерк. Но в своем «сегодняшнем» 
плане - по-моему там никакой вторичности нет, а в чисто-историческом - какая ж может быть первичность, ведь это только наплывами и почти общеизвестное. Учитель с ребятами - самые первичные, даже на фото они у нас есть. Я не думал, что они создают стилизацию, я просто показал, какой народ туда ходит /не старше «Запорожца»/. Почему Захар не спал дома? - для меня самого загадка. Но без этого не было бы и рассказа.

Того, что делаю с языком - уступить не могу: затрепанным языком ничего не выразишь. Упреки в «славянофильстве» уже слышу не первый раз. Это очень неточное /и брезгливо-употребляемое/ выражение для обозначения национальной боли людьми, у которых боли этой нет. Что ж, кто как чувствует [...] Что касается «Танго»- может быть это и блестяще, но стал я думать, что всякая сатира - второй /если не третий/ сорт искусства: посмеялись, повосхищались - да и как с гуся вода. Сатира не развивает души, и поэтому она почти бесплодна.»

[Miła Anno Władysławowna! Dziękuję Pani za kolejną bezkompromisową opinię. Proszę, niech Pani zawsze zostaje taka!

$\mathrm{Z}$ ciekawością przemyślę to, co Pani napisała /niezbyt często zgadzam się od razu, czasem dopiero potem/. Że to nie opowiadanie w sensie dosłownym - oczywiście, jest i publicystyka, i szkic. Ale w moim „dzisiejszym" planie - według mnie tam nie ma żadnej wtórności, a w czysto historycznym - jakaż może być pierwotność, przecież to tylko przypływy i prawie powszechnie znane. Nauczyciel z dziećmi - najbardziej pierwotni, nawet są u nas na zdjęciu. Nie myślałem, że oni stwarzają stylizację, po prostu pokazałem, jaki naród tu chodzi / nie starszy od Zaporożca/. Dlaczego Zachar nie spał w domu? - dla mnie samego zagadka. Ale bez tego nie byłoby opowiadania.

$\mathrm{Z}$ tego, co robię z językiem - zrezygnować nie mogę: niechlujnym językiem niczego nie wyrazisz. Zarzutów o „słowianofilstwo” wysłuchuję nie po raz pierwszy. To bardzo nieścisłe i ze wstrętem używane określenie dla zasygnalizowania bólu narodowego przez ludzi, którzy są pozbawieni tego bólu. Cóż, kto jak odczuwa [...] Jeżeli chodzi o Tango - być może to błyskotliwe, lecz zacząłem rozważać, że wszelka satyra - drugi /jeżeli nie trzeci/ gatunek sztuki: pośmieli się, pozachwycali się i jak woda po gęsi. 
Satyra nie podnosi na duchu i dlatego jest prawie bezowocna.]

Listy odzwierciedlają klimat, nastrój intelektualny, mentalność tamtych czasów, w ujęciu metaforycznym „odwilż polityczną” i „,zakręcanie kurków”. List z dnia 5 stycznia 1966 roku:

„[...] Этой осенью постигла нас целая полоса бед, среди которых главная - изьятие моего романа. Жаловался на самый верх - но вернуть не удалось. Потом пытался напечатать пьесу - даже Твардовский отказался. В несколько журналов предлагал подборку из четырех рассказов - но только один из них, вероятно, появится в «Новом мире»... [...]»

[Tej jesieni spadło na nas całe pasmo kłopotów, wśród których główny - wycofanie mojej powieści. Skarżyłem się na sam szczyt - ale zwrócić nie udało się. Następnie próbowałem opublikować sztukę - nawet Twardowski odmówił. Do kilku czasopism proponowałem zestaw czterech opowiadań - lecz tylko jedno z nich pojawi się zapewne w piśmie „Nowyj Mir'].

Listy Sołżenicyna zawierają różnego rodzaju ciekawostki, autentyczne autorskie komentarze, dotyczące chociażby leksemu, który, jak uważała krytyka, pisarz wprowadził do języka rosyjskiego. List z 4 października 1966 roku:

«Слово «показуха» не изобретено мною, а является укоренившимся лагерным термином. Как многим лагерным словам, ему тоже судьба хлынуть в общую речь. Очевидно, в какой то степени я этому процессу помог, но не думаю, чтобы оно вошло в общую речь только через Ивана Денисовича. Лагерный язык любит суффиксы фамильярные и уничижительные. В данном случае огрубление: «показуха» - сделанное на показ, может быть даже неумело, грубо, так что подделка видна внимательному глазу - и уж обязательно плохого /даже - никакого/ качества. Подобное тому - раскидывать чернуху - рассказывать небылую чужь, пускать темноту. Суффиксы уничижительные - больничка, свиданка, мамка. Лагерник как бы хочет высмеять все святое, даже то, чем сокровенно дорожит. 
Статью Лакшина в смысле ее возможного воздействия, верней в смысле того, что она поКазывает какую-то перемену со мной Вы переоцениваете: ничего со мной не изменилось, еще долго будет трудно, а напечататься почти невозможно. Тот же «Новый мир» в тот же месяц, когда набиралась статья Лакшина, отказался от печатания моего «Ракового Корпуса». Как Вы? Ничего никогда о себе не напишете! А я о Вас нередко вспоминаю. Какая-то загадка осталась для меня вокруг Вас.

[Słowo „pokazucha” nie jest moim wynalazkiem, jest to zakorzeniony termin łagrowy. Jego przeznaczeniem, jak wielu słów łagrowych, jest przedostać się do języka ogólnego. Możliwe, że w jakimś stopniu przyczyniłem się do tego procesu, lecz nie sądzę, żeby weszło ono do języka ogólnego wyłącznie za pośrednictwem Iwana Denisowicza. Język łagrowy lubi familiarne i pogardliwe sufiksy. W tym wypadku augmentativum: ,pokazucha" - coś zrobionego na pokaz, może nawet nieumiejętnie, niezdarnie, tak, że podróbka widoczna dla uważnego oka i już koniecznie złej /a nawet żadnej/ jakości. Podobne do tego - „rozrzucać czernuchę” - opowiadać niebywałe głupstwa, ściemniać. Sufiksy zdrabniające - szpitalik, spotkanko, mamka. Łagrowiec jakby chce wyśmiać wszystko święte, nawet to, co dla niego drogie.

Artykuł Łakszina w sensie jego oddziaływania, raczej w sensie, że on pokazuje jakieś zmiany u mnie, Pani przecenia. Nic się u mnie nie zmieniło, jeszcze długo będzie trudno, a publikować prawie niemożliwie. Tenże „Nowyj Mir”, w tym samym miesiącu, jak składano artykuł Łakszina, odmówił opublikowania mojego Oddziału chorych na raka. A jak Pani? Nigdy niczego o sobie nie napisze! Ja zaś nierzadko wspominam o Pani. Jakaś zagadka pozostała dla mnie wokół Pani.]

Sołżenicyn zwracał się do swojej korespondentki z Wilna w sprawach delikatnych i trudnych nawet dla bardzo doświadczonego odbiorcy. List z 15 listopada 1973 roku:

«Милая Анна Владиславовна! [...] Мне понадобилась тонкая ответственная справка по Польше - и я рискую у Вас ее запросить. По- 
лагаюсь очень на Ваш авторитет, а свравка для Вас, я надеюсь, не составит слишком большого труда. Даже хотел бы, чтобы Вы обошлись без лишних книжных розысков, а написали бы свое суммарное впечатление.

Вот вопрос. Если судить по польской литературе (и по польской общественной жизни, по крупным именам), - проявлялась ли в Польше в период примерно с 1620 г. по 1780-90-е. (до окончательного раздела ее) раскаяние, сожаление о действиях Польши на Украине, в Беларуссии, в предыдущий перед тем период, и по поводу посягательств подчинить Россию в Смутное время.

Я имею в виду движение раскаяния подобное тому, какое владело русским обществом по крайней мере с 1830 по 1917 гг.

Я же думаю, что только в одной России могло быть такое общественное раскаяние, а в Польше ничего подобного не было и действия государства считались просто естественными, подчинение украинских хлопов польским панам - то же».

Но хотелось бы мне не ошибаться, иметь суждение ответственHoe.

Итак, если можете - дайте такую справку. Напечатайте ее на машинке или от руки, без обращения и без подписи, адресат поймет и мне передадут.

И еще маленький вопрос. Верно ли, что родина Мицкевича - др. Заосье близ Барановичей? Как долго он там жил живал?»

[Miła Anno Władysławowna! Potrzebna mi delikatna, odpowiedzialna informacja o Polsce i ośmielam się poprosić Panią o to. Bardzo polegam na Pani autorytecie, a informacja, mam nadzieję, nie sprawi Pani wielkiego kłopotu. Nawet chciałbym, żeby Pani się obeszła bez zbędnych książkowych poszukiwań, zaś opisała swoje sumaryczne wrażenie.

Oto pytanie. Jeżeli sądzić na podstawie literatury polskiej (na podstawie polskiego życia społecznego i wielkich imion): czy przejawiała się w Polsce pokuta w okresie, w przybliżeniu, od 1620 roku po lata 1780 1790 (do ostatecznego jej podziału), jakieś ubolewanie z powodu działań na Ukrainie, Białorusi w poprzedzającym ten okresie i z powodu zakusów na podporządkowanie Rosji w smutnym czasie? 
Mam na uwadze ruch pokuty, który zawładnął społeczeństwem rosyjskim co najmniej od 1830 po 1917 rok.

Myślę, że jedynie w Rosji była możliwa taka wielka społeczna pokuta, a w Polsce niczego podobnego nie było i działania państwa były uważane za naturalne, podporządkowanie ukraińskich chłopów przez polskich panów - też.

Lecz chciałbym się nie mylić, mieć zdanie wyważone.

A zatem, jeżeli to możliwe, proszę o taką informację. Proszę nadrukować to na maszynie bądź od ręki, bez zwrotu [honoryfikatywnego zapewne - A. B.] i podpisu, adresat zrozumie i mnie przekażą.

I jeszcze małe pytanie. Czy to prawda, że ojczyzna Mickiewicza - wieś Zaosie koło Baranowicz? Jak długo tam żył, przebywał?]

Wiadomo, że przedstawiona tu korespondencja ma wymiar niekompletny. Przybliżyłem tylko fragmenty listów pisarza, zawierających informację, która może zainteresować badacza jego spuścizny literackiej. Większość listów okolicznościowych, pisanych z okazji świąt, jest dodatkowo inkrustowana w różne „kwiatki” estetyczne. Myślę, że trudno będzie odnaleźć listy Anny Kaupuż do pisarza. Teksty paraliterackie Sołżenicyna mogą zawierać wzmianki o jego litewskiej powierniczce. Jeżeli chodzi o tożsamość, podobnie jak w rozmowach ze mną, tak też w listach do Sołżenicyna, Anna Kaupuż lubiła podkreślać, że jest Polką pochodzącą z Łatgalii.

\section{Refleksje osobiste}

Los Anny Kaupuż ułożył się dramatycznie. W latach 90. ciężko zachorowała. Musiała wymienić swoje mieszkanie przy ulicy Basanavičiusa na mniejsze. Kiedy wróciła ze szpitala, siedząc na krześle w swoim byłym mieszkaniu obserwowała, jak jego nabywcy wynosili cenne książki, gromadzone przez całe jej życie. Książki te, w przeważającej większości, trafiły na śmietnik.

Za udzieloną mi informację oraz listy bardzo jestem wdzięczny pani Ludmile Siekackiej, byłej pracowniczce Katedry Języka Polskiego i Literatury, którą kierowała niegdyś Anna Kaupuż. To właśnie z archiwum Siekackiej pochodzi omawiana przeze mnie korespondencja.

We wspomnieniach Pani Ludmiły pozostała Anna Kaupuż jako dobry, wspaniały człowiek, jako bardzo inteligentna, ciesząca się autorytetem oso- 
ba, która zawsze służyła pomocą młodym naukowcom. Była nieco zamknięta, skromna, wyróżniała ją niezwykle głęboka duchowość.

Ludmiłę Siekacką znam od lat. Przez długi czas pracowała w szkole, zwana czasem Telimeną. Zostały jeszcze na Litwie ogniska polskości, szczerej i bezinteresownej. Jednym z takich ognisk jest dom „Ludki” Siekackiej, gdzie realne staje się podróżowanie w czasie. Dla mnie ta przestrzeń kojarzy się z okresem międzywojennym, nowoczesność tutaj jakby znika, nawet zegar wybija godziny w rytmie dawnego czasu. Imię Ludmiły Siekackiej spotkałem także na łamach pisma „Bibliotekarz Podlaski” we wspomnieniach profesor Aliny Kowalczykowej o legendarnej wycieczce we wrześniu 1967 roku do stolicy polskiego romantyzmu, zorganizowanej przez Instytut Badań Literackich PAN. Uczestnikami tej wycieczki byli, między innymi, Michał Głowiński, Maria Janion, Ryszard Przybylski, Zofia Stefanowska, Kazimierz Wyka, Maria Żmigrodzka i inni. Zaopiekowała się tą grupą właśnie Ludmiła Siekacka, i to w czasach, kiedy „zbytnia otwartość mogła okazać się dla wilnian niebezpieczna"10.

Alina Kowalczykowa świetnie odmalowała dziwaczną atmosferę tych czasów, na które akurat przypadała korespondencja Anny Kaupuż z pisarzem rosyjskim, aurę nawet dla przybywających na Litwę z PRL-u będącą wielkim zaskoczeniem.

Jeżeli chodzi o Annę Kaupuż, pochodzącą z Łatgalii badaczkę, chciałbym na zakończenie zacytować fragment arcydzieła polskiej literatury:

W pomroce życia, gdzie po omacku błądzi nieszczęsny rodzaj ludzki, gdzie jedni rozbijają się o zawady, inni spadają w otchłań, a pewnej drogi nikt nie zna, gdzie na skrępowanego przesądami człowieka poluje zły przypadek, nędza i nienawiść po ciemnych manowcach życia również uwijają się latarnicy. Każdy niesie drobny płomyk nad głową, każdy na swojej ścieżce roznieca światło, żyje niepoznany, trudzi się nieoceniony, a potem znika jak cień... ${ }^{11}$

10 A. Kowalczykowa, Wyprawa do Wilna, „Bibliotekarz Podlaski” 2014, nr 28, s. 172.

11 B. Prus, Cienie, [w:] Pozytywizm. Teksty, Warszawa 2000, s. 121-122. 


\section{Bibliografia}

Anna Kaupuż (1924-1994), „Kwartalnik Historii, Nauki i Techniki” 1995, 40, nr 3, S. 171-174.

Kaupuż A., Iz istoriji polskoj orfografii w Wilnie w pierwoj treti XIX wieka, [w: ]Acta Baltica-Slavica" 1973, R. VIII, s. 169-181.

Kaupuż A., Kochanowski na Litwie. Przekłady tekstów Jana z Czarnolasu na język litewski, [w:] Jan Kochanowski 1584-1984. Epoka - twórczość - recepcja. Prace Międzynarodowej i Międzydyscyplinarnej Konferencji Naukowej, zorganizowanej w Warszawie 15-19 października 1984 r. staraniem Instytutu Badań Literackich i innych instytucji, T. II, pod red. J. Pelca, P. Buchwald-Pelcowej i B. Otwinowskiej, Lublin 1989, s. 79-95.

Kaupuż A., Matierialy k izuczeniju istorii rezjanskich goworow, [w:] Wokół języka. Rozprawy i studia poświęcone pamięci profesora Mieczysława Szymczaka, red. M. Basaj i inni, Wrocław 1988, s. 191-195.

Kaupuż A., Nežinomas XIX a. pradžios rankraštis lietuviu ir lenku kalbomis, [w:] "Lietuvos TSR Aukštuju mokyklų mokslo darbai“, „Literatūra“ VIII, Vilnius 1965, S. $233-272$.

Kaupuż A., Niekotoryje dopolnitielnyje swiedienija o litowskich diejatielach kultury naczala XIX wieka w pismach prof. russkoj slowiesnosti Wilenskogo uniwiersitieta I. N. Łobojko, [w:] „Naucznyje trudy wysszich ucziebnych zawiedienij Litowskoj SSR“, «Litieratura» VI, Vilnius 1963, c. 207-221.

Kaupuż A., O litewskich przekładach Mickiewicza, „Rocznik Towarzystwa Literackiego im. Adama Mickiewicza” 1979, R. XII, s. 75-82.

Kaupuż A., W sprawie udziału Jana Baudouina de Courtenay w redagowaniu słownika Antanasa Juški, [w:] Bałto-słowiańskie związki językowe, pod red. M. Kondratiuka, Wrocław-Warszawa-Kraków 1990, s. 187-197.

Kowalczykowa A., Wyprawa do Wilna, „Bibliotekarz Podlaski” 2014, nr 28, s. 172. Masojć I., Sawaniewska-Mochowa Z., Anna Kaupuż - zapomniana badaczka polszczyzny i związków międzykulturowych na kresach, [w:] Studia nad polszczyzną kresową, pod red. J. Riegera, Warszawa 2010, s. 9-17.

Prus B., Cienie, [w:] Pozytywizm. Teksty, Warszawa 2000, s. 121-122. 